DOI: https://doi.org/10.47405/mjssh.v7i1.1237

\begin{tabular}{|c|c|}
\hline 4 & Malaysian Journal of Social Sciences and Humanities (MJSSH) \\
\hline $\begin{array}{l}\text { Malaysian Journal of } \\
\text { Social sciences and }\end{array}$ & Volume 7, Issue 1, January 2022 \\
\hline (MJ-sSH) & e-ISSN : 2504-8562 \\
\hline & $\begin{array}{l}\text { Journal home page: } \\
\text { www.msocialsciences.com }\end{array}$ \\
\hline
\end{tabular}

\title{
Neuromarketing: The Philosophy and Culture of Consumerism in Indonesia
}

\author{
Asra Al Fauzi ${ }^{1,2}$, Eko Armada Riyanto ${ }^{1}$ \\ ${ }_{1}^{1}$ Widya Mandala Catholic University, Surabaya, Indonesia \\ ${ }^{2}$ Faculty of Medicine Universitas Airlangga, Surabaya, Indonesia \\ Correspondence: Asra Al Fauzi (asrafauzi@yahoo.com)
}

\begin{abstract}
Neuromarketing is a revolutionary idea, which combines several disciplines such as psychology, economics, and neuroscience. Indonesia as a developing country that has experienced a fairly rapid economic escalation in the past decade, with the potential for a consumer culture as well as a large purchasing capacity, is a viable market for the application of neuromarketing which is also developing in the world. This review aims to learn more about the idea of neuromarketing, its relation to consumerism culture, and its opportunities in the Indonesian market. For the relevance of the study, this review has also involved the field of neuroscience to discuss philosophical approaches from the use of the subconscious mind, consumerism culture, and the application of neuromarketing in Indonesia today which are known to have successfully utilized neuromarketing principles to boost their sales. However, this technique is not without challenges. In this study, we identified at least some problems, both related to ethics, effectiveness for primary products, to expensive research tools. However, despite these problems, we consider that the use of neuromarketing still has good potential to be applied more widely in Indonesia.
\end{abstract}

Keywords: Neuromarketing, philosophy, consumerism, economy, Indonesia

\section{Introduction}

Neuromarketing is a revolutionary idea in economics that combines several disciplines such as psychology, economics, especially marketing, and neuroscience (Lee et al., 2007; Lim, 2018; Ulman et al., 2014). The basic concept of neuromarketing is that it relies on sensory stimuli that arise when a person sees certain visuals. If it is associated with the field of marketing, visuals in this case can be the name, brand, and logo of a particular product (Castro et al., 2021; Kotsi et al., 2018; Vecchiato et al., 2011).

The idea of stimulating a person's sensory stimulation through a visual approach is now starting to become a mainstay by various brands around the world, and is expected to increase the quantity of selling their products more effectively. In fact, furthermore, now the use of sound, color, atmosphere, touch, smell, music, and certain architecture of a store that sells a product, is considered to have a pleasant influence on customers, and with these deliberately built positive impressions, consumers not only become associated with the brand or product being sold but are also unconsciously forced to buy from those stores and then recommend it to their friends and family as well (Krishna, 2012). This approach is often used by companies that are serious about studying their target consumers while trying to meet their specific needs through neuromarketing principles (Devi Devaru, n.d.). 
An in-depth study of this phenomenon has been carried out using brain imaging like MRI, EEG, PET, etc. to assess consumers' mental reactions to certain products, advertisements, and brands. This technology was developed at Harvard in 1990, and the idea that eventually became known as neuromarketing was based on the fact that ninety percent of emotions are stored in the subconscious mind which needs to be stimulated to elicit the desired reactions in a person by motivating their cognitive and psychological functioning that help them develop choosing behavior, for example, when buying a particular product or brand (Alvino et al., 2020; Fugate, 2007; Giraldi et al., 2014).

Indonesia has become one of the countries with rapid economic growth in the last decade, with a large consumerism culture, as well as its purchasing capacity. These are some of the essential and potential factors in the application of the neuromarketing philosophy (Heryanto, 2005; Lu \& Lu, 2009; Myers \& Kent, 2003).

Indonesia, with a population of around 250 million people, is poised to become one of the largest consumers in the world market in the next few years. With technological disruption that is starting to develop and dominate domestic markets, this is another factor that can influence the use of the concept of neuromarketing in consumer culture. Therefore, this review aims to dig deeper into the opportunities and challenges of the neuromarketing idea, its relation to the philosophy of consumerism culture in Indonesia (Evers \& Gerke, 2016; Lu \& Lu, 2009).

\section{Literature Review}

\section{Neuromarketing and the subconscious mind}

North, Hargreaves, \& McKendrick (1999) in their research, studied the effect of music played in a store on wine selection. The research found that on days when German music was playing, Germanmade wine sales were higher than French-made wine sales, whereas when French music was played, French-made wine sold more than German-made wine (North et al., 1999). However, there is an interesting discovery. When shoppers were asked whether the music playing affected their wine choice, more than $90 \%$ of the respondents answered no. The study shows that the decision to buy can be influenced by things that we are sometimes not aware of. However, this study also raises several questions: Do we make decisions based on facts, reason, and logic? Or do we make decisions based on emotions, feelings, and intuition?

As it turns out, $95 \%$ of our decisions to buy something are determined by the subconscious mind, and this is where neuroscience meets marketing science. Although there is still skepticism by some parties, the application of neuromarketing among business people is starting to develop, mainly because traditional marketing methods cannot provide an understanding of consumers' subconscious emotional experiences.

Businessmen are now starting to adopt a more humane approach in marketing their products (Anggadwita et al., 2021; Parente, 2020). Many companies are beginning to try to understand more about the human psyche, which Carl Jung divided into three components: the conscious (ego), the personal unconscious, and the collective unconscious (Jung, 2014a). The components of the collective unconscious are divided into 12 basic patterns, namely wise, innocent, explorer, leader, creator, caregiver, magician, hero, rebel, lover, comedian, and orphan (Jung, 2014a, 2014b).

Businessmen have found a way to get their message across by influencing the subconscious of consumers, and by understanding the factors that influence the subconscious of these consumers, they can bring in very promising financial returns (Aspara et al., 2015). Google, for example, where minor changes to the colors used have resulted in an increase in ad revenue of US\$200 million. Google's designers initially noticed that more users clicked on a link when the link was in a certain blue, compared to other blues. 
Therefore, Google then conducted an A/B test covering 41 different shades of blue and found that a purplish blue was more conducive to generating clicks than a blue tone of green. This discovery became the basis of the company's decision to change the color of its links. Users who choose to click on links based on color don't do so consciously. The decision is the result of their subconscious role in deciding.

\section{Advertising and Consumerism}

Consumerism must be seen within the framework of changing society's culture with all the factors that affect and influenced it. With regard to economic factors, namely increased production, consumerism is part of changing the lifestyle of community groups that have been pushed up to become the urban middle class (Wijaya, 2007).

D. L. Clough said, perhaps consumerize can be understood as a proportional meaning of a group of the human population, which has reached a certain level of wealth, because their basic needs have reached a surplus level. Another characteristic of a consumerist society is the consumption of luxury goods. It becomes something that is very meaningful and determines their social identity (Davie et al., n.d.).

An evolutionist named Thorstein Veblen tried to find an understanding of economic activity through the concept of neo-Darwinism, related to natural selection. According to him, consumptive culture is one of the characteristics of competitive behavior that aims to give an impression to others and to achieve certain social status. The motivation to buy a luxury vehicle, for example, is one of the efforts to show others that he is a rich person who deserves to own the item.

Meanwhile, advertising, with its various functions, has accompanied the consumerism culture that has begun to spread and influence the community, especially teenagers and young adults, said Caspi and Robert. These age groups often expose themselves through music video advertisements. These actions actually illustrate the vulnerability of their unstable souls and are looking for a more prestigious and influential figure (Caspi \& Roberts, 2009).

The more vulnerable their sense of security is in their soul, the greater the chance of changing their personality. This continues to make it easier for them to love and use certain brands of a product that builds their new self-image (Rhee \& Johnson, 2012). In this fragile condition, it is not surprising that teenagers and young adults are influenced to imitate the behavior of artists who become ambassadors for a product (Giles \& Maltby, 2004). If their favorite artist uses a certain electronic product, such as an iPhone or Samsung with a specific message and type, they are more likely to have that too (Voorveld et al., 2017).

Compared to the older generations, youth and young adults exhibit a higher life of materialism (Jaspers \& Pieters, 2016). According to Nelson and McLeod, past research shows that awareness of a brand not only indicates that teenagers and young people are vulnerable to the influence of advertising but also shows what they are (Nelson \& McLeod, 2005). Materialists tend to like branded products. They believe that having products with expensive and well-known brands will make them appear successful and happy (Richins \& Dawson, 1992).

The dominant moral critique of consumerism considers that consumerism has increased global uniformity, an attitude of not wanting to lose, competition, individualism, irrationalism, superficial meaning, and Americanization (Miller, 1997). In other words, consumerism endangers social solidarity, destroys personality, and threatens the survival of noble values in local cultural traditions. That judgment is hard to argue with, although anthropological research by Daniel Miller shows that such generalizations are not always accurate (Miller, 1997).

Based on the simple theology of life, which does have a solid foundation in various biblical sources, theologians also tend to take an anti-consumerist position. Their perspective is relevant to the context of Indonesian society which is known to be very passionate about consumption but not prominent in production. If the process of decadence in Western society is understandable because it is a 
consequence of excess production and therefore has a positive impact on stimulating their economy (Higginson, 2002), consumerism in Indonesian society depends on the supply of foreign products and therefore adds to the burden on the domestic economy. The simple lifestyle of the Indonesian people, which is quite rooted in local traditions, has not resulted in a productive culture as was the case with the monasteries, Puritans, and Quakers in Europe.

Because the productive culture is not strong enough, it is difficult for the consumerization process in Indonesia to be expected to encourage the transformation of production as in the theory of Campbell and Berger. Thus, as far as the Indonesian context is the focus of reflection, there is no strong enough reason to completely abandon the critical position on consumption behavior which has been the dominant attitude of theological circles.

\section{Methodology}

The research was conducted through qualitative method to address the research problem. This method is best used as it aims to investigate human phenomena and investigate interpretations and meaning that are unknown and needed to be explored. Literature study is a series of activities related to using library data collection methods, reading and record, and manage research materials. This technique is carried out with the aim of revealing various theories that are relevant to the problems being faced/researched as reference material in the discussion of research results.

\section{Result}

The adopted policy of deregulation, with all its effects and consequences, marks the openness of Indonesia to the global world. The adaptation of Indonesian economic development to the forces of globalization had an effect on shifting oil-led growth to trade-led growth and providing more access to the global culture of consumerism. Through deregulation, Indonesia became an integral part of the global economy. It has made the world its marketplace and reciprocated by inviting the world to take a stake in the nation's development (Prawiro, 1998). Middle class consumers in Indonesia can be viewed in the context of this market globalization (Prawiro, 1998).

The liberalization and deregulation policy of Indonesia had significant effects on its systems of finance, banking, and production by helping to stimulate the structural changes of occupation and creating various middle-class jobs. The increase in these kinds of jobs has been a primary factor in the rise of a new middle class in Indonesia, and this growth of the middle class was the targeted goal of Indonesian economic development.

According to Takashi Shiraishi, an analyst of comparative development in Southeast Asia, the emergence of a middle class in Indonesia can be traced back to the economic boom years of 19871997. The 1996 census data indicates that those who were classified as professionals and technicians, executives and managers, and white-collar office workers constituted 8.6 percent of the total working population and totaled 7.4 million people (Shiraishi, 2004). However, it is important to keep in mind that, compared to the working population, the census-based number of middle class in Indonesia was relatively small. Concerning jobs and lifestyle, the Indonesian people who could have been categorized as prosperous and urban were less than $5 \%$ of the population, or approximately 7.3 million people in 1980 (Mackie, 1990).

In Jakarta, where Indonesian economic development is more centralized, the new middle class is growing more extensively than in other cities in Indonesia. According to Shiraishi, economic development has transformed Jakarta into an emerging middle-class city, with the biggest growth from 1987-1997, and a current population of 10 million. Most of the middle-class people in Jakarta consist of professionals (Shiraishi, 2004). The consumption pattern and lifestyles of those middleclass people are featured in weekly and monthly magazines and appear on TV talk shows: young banking 
professionals are shown dressing in brand name suits, driving expensive cars, and eating out in posh Italian, French, and Japanese restaurants (Gerke, 1995).

Even though Indonesia is slowly becoming a considerable economic power in the world, however, the use of neuromarketing in domestic economic practices still seems unsatisfactory. In fact, Indonesians may still feel unfamiliar with the word of "neuromarketing" (Suyadi et al., 2021). However, the concept of neuromarketing through the use of technological and scientific advances through neuroscience studies has been widely applied by marketers globally in marketing their products (Fugate, 2007).

With the hope of making appropriate marketing strategies and being able to meet the needs and desires of consumers in the Indonesian property industry, rumah123.com, which is one of the property search engine companies in Indonesia, in 2018, began conducting research on consumer behavior using eyetracking technology, a process of measuring eye movement to determine the location and type of information a person sees, the order in which the information is placed, and how long their gaze stays in a particular place (Aliyah, 2019). This technology is the first time used in the property industry in Indonesia.

Using an advanced algorithm, this technology allows the user to measure the position of the eye and determine exactly where to focus. Eye-tracking technology can produce new insights and perspectives on consumer behavior that cannot be provided by other conventional research methods such as surveys, interviews, and even FGDs (Galesic et al., 2008). The use of biometric technology is able to answer more accurately the 'mystery' of how buying decisions are made (Biometric Technology: Authentication, Biocryptography, and Cloud-Based ... - Ravi Das - Google Books, n.d.).

\section{Discussion}

The application of neuromarketing to various industries brings up new opportunities as well as new challenges (Ferman \& Kurtoglu, 2020). For decades, marketers have been trying to understand human behavior with traditional measuring tools such as focus groups and interviews to clarify what consumers truly want. Unfortunately, consumers are not always able to articulate their true feelings (Kenning \& Plassmann, 2008; Thaler, 2000) which limit the usability of the traditional marketing tools. The disclosure of the new science called neuroscience has revealed what was invisible to traditional market research (Ariely \& Berns, 2010b; Dimoka et al., 2012; Knutson \& Cooper, 2005). It enables marketers to look into the consumer's unconscious mind, thoughts and feelings (Hubert \& Kenning, 2008). Neuroscience studies human automatic and unconscious systems (Hubert \& Kenning, 2008) by measuring the blood flow in the brain in contrast to their current action. The findings of neuroscience evoked interest in the landscape of marketing (Knutson \& Cooper, 2005) at least for the following two reasons. First marketing hopes "it might be cheaper and faster than current marketing tools" and secondly is the expectation that "it could provide hidden information about products that would otherwise be unobtainable" (Ariely \& Berns, 2010b). With specific neuroscientific techniques such as the functional Magnetic Resonance Imaging (fMRI) and Electroencephalography (EEG) the impact of marketing stimuli on consumers can now be studied in a different way.

Although neuromarketing promises significant benefits, the technique to capture people's unconscious thoughts for a commercial purpose has raised several criticisms on consumer deception and privacy invasiveness (Hammou et al., 2013; Wilson et al., 2008). One can argue that neuromarketers are able to manipulate consumer behaviour (Palmer \& Hedberg, 2012) and consumer ability to make logical purchasing decisions. In addition to the above, consumer rights protection and the threat to autonomy are questioned (Egrie \& Bietsch, 2014).

However, ethical issues have not been addressed only to marketing but also to communications, sociology, politics and psychology. The effects of advertising, according to Morin (Morin, 2011) can contribute to society beyond simply finding the "Buy bottom ". The application of neuroscience can provide a basis of understanding of how humans create, store, recall and relate information as it does 
with a mark in their daily lives. It would also be possible to discover whether some aspects of marketing activities trigger negative effects such as consumerism. In fact, the field of neuro-marketing should be considered a legitimate and important area that allows understanding human behavior in extremely important business relationships. Ethics should not be a stranger field to any professional as it relates to society in general. Adina Roskies defines neuro-ethics research as the research on how to deal with social issues of disease, normality, mortality, lifestyle and philosophy of life in the light of understanding of the brain mechanisms that underlie all these issues (Bonete, 2010). Neuro-imaging studies have even suggested that neural activity precedes conscious intention questioning free will, especially if this can be monitored by an external observer (Madan, 2010). However, the potential restriction of free will and the possible invasion of privacy require the evaluation of academic and government regulation, consumers should know who is collecting this data and the potential uses of the information (Wilson et al., 2008).

Despite how exciting and revolutionary this new science may be, it is important to note that the neuroscience approach to marketing cannot be applied to all products. This approach may not be very effective if used to market primary needs products, because for primary needs, consumers tend to be more motivated by price rather than certain visualizations (al POP \& Maria IORGA, 2012; Pelău \& Marketing, 2011).

In addition, the neuromarketing approach also often clashes with ethical issues, considering that neuromarketing provides insight into processes that humans are not aware of (Lee et al., 2007; Lim, 2018). One of the greatest fears posed by neuromarketing is the possibility of discovering and exploiting the 'buy button' in the human brain, which businesses can then use to tempt consumers to shop and increase their sales (Ulman et al., 2014). Marketers are interested in finding more about consumer choice-making and activation patterns that predict consumer behaviour, in order to better understand what consumers need and better predict it in the future. The "game" takes place between the five senses that engage the consumer and neuroimaging tools offer the opportunity to examine the social behaviors using knowledge about associated brain functions. So, there are questions raised, such as: Should marketers have access to consumers' unconscious choices? To what use should such information be put? But electroencephalography or functional magnetic resonance imaging are neither able to read subjects' thoughts, nor to manipulate human mind (Bercea Olteanu, 2015).

Businesses that use neuroimaging devices in market research should end public fears such as the ones that they might be able to read the mind of the consumers and solve this issue by being transparent in their steps: notify the subjects on the purpose of the study and offer their customers all the information concerning the way they retrieved the results. Besides understanding the responsibility of using results from neuromarketing studies, researchers should also be careful when analyzing the data gathered. For example, $1 \%$ of the population present abnormal findings (Ariely \& Berns, 2010a) that lead to false positives. Also, in case there is information about subjects' preferences that arises outside the scope of the research questions, researchers should be careful with these insights and proceed by always considering the interests of the consumer (Bercea Olteanu, 2015).

In addition, the equipment used to conduct neuromarketing research is relatively expensive when compared to the equipment needed to conduct traditional marketing research (Sebastian, 2014; Singh, 2020). This can be a barrier for small companies to adopt a neuromarketing approach, especially in a developing country like Indonesia (Kottier, 2014).

\section{Conclusion}

Based on neuroscience and behavioral science, it is found that most people make irrational purchasing decisions with the help of the subconscious mind. There are many things that were unexpected before, turned out to be a consideration for consumers when determining the product of their choice. As for the criticisms raised regarding this method, it can be a double-edged sword; its application can be good or bad, ultimately the outcome depends on the goals and how a company implements it. To this day, neuromarketing is still a relatively new concept and has not been adopted and used massively, 
including in Indonesia. However, the benefits and information that this science can provide indicate a promising future for its application although in empirical reality, it will also face challenges as well as diverse culture of consumerism and various ethical-related issues.

\section{References}

Aliyah, K. N. (2019). Studi Prinsip Dasar Etika Bisnis Islam terhadap Implementasi Biometrika Neuromarketing dalam Strategi Pemasaran.

al POP, N., \& Maria IORGA, A. (2012). A New Challenge For Contemporary MarketingNeuromarketing. Challenges for the Knowledge Society, 7(4), 631-644.

Alvino, L., Pavone, L., Abhishta, A., \& Robben, H. (2020). Picking Your Brains: Where and How Neuroscience Tools Can Enhance Marketing Research. Frontiers in Neuroscience, 14, 577666. https://doi.org/10.3389/FNINS.2020.577666

Anggadwita, G., Dana, L. P., Ramadani, V., \& Ramadan, R. Y. (2021). Empowering Islamic boarding schools by applying the humane entrepreneurship approach: the case of Indonesia. International Journal of Entrepreneurial Behaviour and Research, 27(6), 1580-1604. https://doi.org/10.1108/IJEBR-11-2020-0797/FULL/XML

Ariely, D., \& Berns, G. S. (2010a). Neuromarketing: the hope and hype of neuroimaging in business. Nature Reviews. Neuroscience, 11(4), 284. https://doi.org/10.1038/NRN2795

Ariely, D., \& Berns, G. S. (2010b). Neuromarketing: the hope and hype of neuroimaging in business. Nature Reviews Neuroscience 2010 11:4, 11(4), 284-292. https://doi.org/10.1038/nrn2795

Aspara, J., Chakravarti, A., \& Hoffmann, A. (2015). Focal versus background goals in consumer financial decision-making: Trading off financial returns for self-expression? European Journal of Marketing, 49(7-8), 1114-1138. https://doi.org/10.1108/EJM-04-2014-0244/FULL/XML

Bagaimana Teknologi Biometric Neuromarketing Membantu Industri Properti di Indonesia. (n.d.). Retrieved December 2, 2021, from https://www.marketeers.com/teknologi-biometricneuromarketing-membantu-industri-properti-di-indonesia/

Bercea Olteanu, M. D. (2015). Neuroethics and responsibility in conducting neuromarketing research. Neuroethics, 8(2), 191-202. https://doi.org/10.1007/S12152-014-9227-Y

Biometric Technology: Authentication, Biocryptography, and Cloud-Based ... - Ravi Das - Google $\begin{array}{llllll}\text { Books. (n.d.). Retrieved } & \text { December 2021, from }\end{array}$ https://books.google.co.id/books?hl=en\&lr=\&id=iJHaBAAAQBAJ\&oi=fnd\&pg=PP1\&dq=bio metric+technology+buying+decisions+are+made\&ots=QzndcCbEpP\&sig=OvGjC39GBGqAtQ $10 \mathrm{jw}-$

sK7e0o20\&redir_esc=y\#v=onepage \&q=biometric\%20technology $\% 20$ buying $\% 20$ decisions $\% 20$ are $\% 20$ made $\& \mathrm{f}=$ false

Bonete, E. (2010). Neuroética práctica. In bajopalabra.es. Desclee De Brouwer. http://www.bajopalabra.es/component/k2/item/download/207_a0320a9e0541886b82a1e9f7b502 $585 \mathrm{e}$

Brainfluence: 100 Ways to Persuade and Convince Consumers with Neuromarketing - Roger Dooley Google Books. (n.d.). Retrieved December 2, 2021, from https://books.google.co.id/books?hl=en\&lr=\&id=-

1JD5aJft1 $\mathrm{oC} \&$ oi $=$ fnd \&pg=PR11\&dq=concept+of+neuromarketing+visuals+in+this+case+can+ be+the+name,+brand,+and+logo\&ots=NCKB4bW0wi\&sig=dC6hNj3GkgXDpoKE9L2LfKJhV aI\&redir_esc $=\mathrm{y} \# \mathrm{v}=$ onepage $\& \mathrm{q} \& \mathrm{f}=$ false

Caspi, A., \& Roberts, B. W. (2009). Personality Development Across the Life Course:The Argument for Change and Continuity. Https://Doi.Org/10.1207/S15327965PLI1202_01, 12(2), 49-66. https://doi.org/10.1207/S15327965PLI1202_01

Castro, W. R. A., Pereira, H. O. L., \& Vera, G. R. (2021). Visual neuromarketing strategies in two shopping malls in the city of C\&uacute;cuta, Colombia/Estrategias de neuromarketing visual en dos centros comerciales de la ciudad de C\&uacute;cuta, Colombia. Cuadernos de Administraci\&oacute; $n, \quad 37(71), \quad 1-15$. https://go.gale.com/ps/i.do?p=AONE\&sw=w\&issn=01204645\&v=2.1\&it=r\&id=GALE\%7CA6 $80931975 \&$ sid $=$ googleScholar\&linkaccess $=$ fulltext 
Davie, M., Grass, T., Holmes, S. R., McDowell, J. C., \& Noble, T. A. (Thomas A. (n.d.). New dictionary of theology: historical and systematic / edited by Martin Davie, Tim Grass, Stephen R. Holmes, John McDowell and T.A. Noble. 1016.

Devi Devaru, S. B. (n.d.). SIGNIFICANCE OF NEUROMARKETING ON CONSUMER BUYING BEHAVIOR. https://doi.org/10.30780/IJTRS.V3.I3.2018.015

Dimoka, A., Banker, R. D., Benbasat, I., Davis, F. D., Dennis, A. R., Gefen, D., Gupta, A., Ischebeck, A., Kenning, P. H., Pavlou, P. A., Müller-Putz, G., Riedl, R., vom Brocke, J., \& Weber, B. (2012). On the use of neurophysiological tools in is research: Developing a research agenda for neurois. MIS Quarterly: Management Information Systems, 36(3), 679-702. https://doi.org/10.2307/41703475

Egrie, J., \& Bietsch, S. (2014). Marketing research ethics: How consumers feel about neuromarketing. 2014 Annual Conference Proceedings Marketing Educators' Teaching Challenges and Career Opportunities , 208. https://www.researchgate.net/profile/NurettinBakir/publication/327981895_Who_is_More_Concerned_with_Marketing_Ethics_A_Study_of _Marketing_and_Non-Marketing_Students/links/5bcc3afba6fdcc03c798e091/Who-is-MoreConcerned-with-Marketing-Ethics-A-Study-of-Marketing-and-Non-MarketingStudents.pdf\#page $=227$

Evers, H. D., \& Gerke, S. (2016). Global Market Cultures and the Construction of Modernity in Southeast Asia: Http://Dx.Doi.Org/10.1177/0725513697050000002, 50(1), 1-14. https://doi.org/10.1177/0725513697050000002

Ferman, A. M., \& Kurtoglu, A. L. (2020). An exploratory research among fashion business leaders and neuromarketing company executives on the perception of applied neuromarketing. Pressacademia, 7(2), 72-80. https://doi.org/10.17261/PRESSACADEMIA.2020.1225

Fugate, D. L. (2007). Neuromarketing: A layman's look at neuroscience and its potential application to marketing practice. Journal of Consumer Marketing, 24(7), 385-394. https://doi.org/10.1108/07363760710834807/FULL/XML

Galesic, M., Tourangeau, R., Couper, M. P., \& Conrad, F. G. (2008). Eye-Tracking DataNew Insights on Response Order Effects and Other Cognitive Shortcuts in Survey Responding. Public Opinion Quarterly, 72(5), 892-913. https://doi.org/10.1093/POQ/NFN059

Gerke, S. (1995). Symbolic consumption and the Indonesian middle class (No. 233). http://www.opengrey.eu/item/display/10068/214265

Giles, D. C., \& Maltby, J. (2004). The role of media figures in adolescent development: relations between autonomy, attachment, and interest in celebrities. Personality and Individual Differences, 36(4), 813-822. https://doi.org/10.1016/S0191-8869(03)00154-5

Giraldi, J. M. E., Henrique, J., \& Oliveira, C. (2014). A Review of Studies on Neuromarketing: Practical Results, Techniques, Contributions and Limitations Country of Origin Image-a firm perspective View project Circular Economy and Value Creation View project. Article in Journal of Management Research. https://doi.org/10.5296/jmr.v6i2.5446

Hammou, K. A., Galib, M. H., \& Melloul, J. (2013). The contributions of neuromarketing in marketing research. Journal of Management Research, 5(4), 20-33. https://search.proquest.com/openview/7008ee2925726baa2db4644260c80e08/1.pdf?pqorigsite $=$ gscholar $\& \mathrm{cbl}=366237$

Heryanto, A. (2005). The years of living luxuriously: Identity politics of Indonesia's new rich. Culture and Privilege in Capitalist Asia, 160-188. https://doi.org/10.4324/9780203982075-14/YEARSLIVING-LUXURIOUSLY

Higginson, R. (2002). Questions of business life: exploring workplace issues from a Christian perspective. Carlisle: Spring Harvest Publishing Division and Authentic Media.

How Customers Think: Essential Insights Into the Mind of the Market - Gerald Zaltman - Google Books. (n.d.). Retrieved December 2, 2021, from https://books.google.co.id/books?hl=en\&lr=\&id=FQk3olZrOdUC\&oi=fnd\&pg=PR9\&dq=95\%2 $5+$ of+our+decisions+to+buy+something+are+determined+by+the+subconscious +mind,+and+th is+is+where+neuroscience+meets+marketing+science\&ots=ThraobG_gu\&sig=3Nt1_HOLnAk GSBoSaMnWFdU_DBM\&redir_esc $=\mathrm{y} \# \mathrm{v}=$ onepage \&q $\& \mathrm{f}=\mathrm{false}$

Hubert, M., \& Kenning, P. (2008). A current overview of consumer neuroscience. Journal of Consumer Behaviour, 7(4-5), 272-292. https://doi.org/10.1002/CB.251 
Jaspers, E. D. T., \& Pieters, R. G. M. (2016). Materialism across the life span: An age-period-cohort analysis. Journal of Personality and Social Psychology, 111(3), 451-473. https://doi.org/10.1037/PSPP0000092

Jung, C. G. (2014a). The archetypes and the collective unconscious. The Archetypes and the Collective Unconscious, 9, 1-546. https://doi.org/10.4324/9781315725642/ARCHETYPESCOLLECTIVE-UNCONSCIOUS-JUNG

Jung, C. G. (2014b). Two essays on analytical psychology. Two Essays on Analytical Psychology, 1372. https://doi.org/10.4324/9781315725895/TWO-ESSAYS-ANALYTICALPSYCHOLOGY-JUNG

Kenning, P. H., \& Plassmann, H. (2008). How neuroscience can inform consumer research. IEEE Transactions on Neural Systems and Rehabilitation Engineering, 16(6), 532-538. https://doi.org/10.1109/TNSRE.2008.2009788

Knutson, B., \& Cooper, J. C. (2005). Functional magnetic resonance imaging of reward prediction. Current Opinion in Neurology, 18(4), 411-417. https://doi.org/10.1097/01.WCO.0000173463.24758.F6

Kotsi, F., Balakrishnan, M. S., Michael, I., \& Ramsøy, T. Z. (2018). Place branding: Aligning multiple stakeholder perception of visual and auditory communication elements. Journal of Destination Marketing \& Management, 7, 112-130. https://doi.org/10.1016/J.JDMM.2016.08.006

Kottier, W. G. (2014). The added value of neuromarketing tools in the area of marketing research.

Krishna, A. (2012). An integrative review of sensory marketing: Engaging the senses to affect perception, judgment and behavior. Journal of Consumer Psychology, 22(3), 332-351. https://doi.org/10.1016/J.JCPS.2011.08.003

Lee, N., Broderick, A. J., \& Chamberlain, L. (2007). What is 'neuromarketing'? A discussion and agenda for future research. International Journal of Psychophysiology, 63(2), 199-204. https://doi.org/10.1016/J.IJPSYCHO.2006.03.007

Lim, W. M. (2018). Demystifying neuromarketing. Journal of Business Research, 91, 205-220. https://doi.org/10.1016/J.JBUSRES.2018.05.036

Lu, L. C., \& Lu, C. J. (2009). Moral Philosophy, Materialism, and Consumer Ethics: An Exploratory Study in Indonesia. Journal of Business Ethics 2009 94:2, 94(2), 193-210. https://doi.org/10.1007/S10551-009-0256-0

Mackie, J. A. C. (1990). Money and the middle class. In R. Tanter \& K. Young (Eds.), The politics of middle class Indonesia. Center for Southeast Asian Studies. https://scholar.google.co.id/scholar?hl=en\&as_sdt=0\%2C5\&q=Money+and+the+middle+class+ mackie\&btnG $=\&$ oq $=$ mone

Madan, C. R. (2010). Neuromarketing: the next step in market research? Eureka, 1(1), 34-42. https://doi.org/10.29173/EUREKA7786

Marketing to the Mind: Right Brain Strategies for Advertising and Marketing - Richard C. Maddock, Richard L. Fulton - Google Books. (n.d.). Retrieved December 2, 2021, from https://books.google.co.id/books?hl=en\&lr=\&id=aYP0-

$\mathrm{hEgc} 18 \mathrm{C} \& \mathrm{oi}=\mathrm{fnd} \& \mathrm{pg}=\mathrm{PP} 11 \& \mathrm{dq}=$ there+is+still+skepticism+by+some+parties+traditional+mar keting+methods+cannot+provide+an+understanding+of+consumers $\% 27+$ subconscious\&ots $=I 5 j$ nuUgNUm\&sig=kZxncGRWnJmRH_seG6bGZo1SjLw\&redir_esc=y\#v=onepage\&q\&f=false

Miller, D. (1997). Could shopping ever really matter. In P. Falk \& C. Campbell (Eds.), The Shopping Experience (p. 43). Sage Publications. https://www.google.com/books?hl=en\&lr=\&id=xpd2CkxWeMoC\&oi=fnd\&pg=PA31\&dq=Cou $\mathrm{ld}+$ shopping+really+matter\&ots=qdhlaaJGDa\&sig=r0PNQH8QWeKxGQffM74NLIJys20

Morin, C. (2011). Neuromarketing: The New Science of Consumer Behavior. Symposium: Consumer Culture in Global Perspective, 48(2), 131-135. https://doi.org/10.1007/S12115-010-9408-1

Myers, N., \& Kent, J. (2003). New consumers: The influence of affluence on the environment. Proceedings of the National Academy of Sciences, 100(8), 4963-4968. https://doi.org/10.1073/PNAS.0438061100

Nelson, M. R., \& McLeod, L. E. (2005). Adolescent brand consciousness and product placements: awareness, liking and perceived effects on self and others. International Journal of Consumer Studies, 29(6), 515-528. https://doi.org/10.1111/J.1470-6431.2005.00429.X 
North, A. C., Hargreaves, D. J., \& McKendrick, J. (1999). The influence of in-store music on wine selections. Journal of Applied Psychology, 84(2), 271-276. https://doi.org/10.1037/00219010.84.2.271

Palmer, D., \& Hedberg, T. (2012). The Ethics of Marketing to Vulnerable Populations. Journal of Business Ethics 2012 116:2, 116(2), 403-413. https://doi.org/10.1007/S10551-012-1476-2

Parente, R. (2020). Digitalization, Consumer Social Responsibility, and Humane Entrepreneurship: Good news from the future? Https://Doi.Org/10.1080/26437015.2020.1714368, 1(1), 56-63. https://doi.org/10.1080/26437015.2020.1714368

Pelău, C., \& Marketing, M. \&. (2011). Analysis Of Consumer Behavior For Different Product Groups. Challenges for the Knowledge Society, 6, 101-114.

Prawiro, R. (1998). Indonesia's Struggle for Economic Development: Pragmatism in Action. In OUP Catalogue. Oxford University Press. https://ideas.repec.org/b/oxp/obooks/9789835600531.html

Rhee, J., \& Johnson, K. K. P. (2012). Investigating relationships between adolescents' liking for an apparel brand and brand self congruency. Young Consumers, 13(1), 74-85. https://doi.org/10.1108/17473611211203957/FULL/XML

Richins, M. L., \& Dawson, S. (1992). A Consumer Values Orientation for Materialism and Its Measurement: Scale Development and Validation. Journal of Consumer Research, 19(3), 303316. https://doi.org/10.1086/209304

Sebastian, V. (2014). Neuromarketing and Evaluation of Cognitive and Emotional Responses of Consumers to Marketing Stimuli. Procedia - Social and Behavioral Sciences, 127, 753-757. https://doi.org/10.1016/J.SBSPRO.2014.03.349

Sensory Marketing: Research on the Sensuality of Products - Google Books. (n.d.). Retrieved December 2 , 2021, from https://books.google.co.id/books?hl=en\&lr=\&id=qfKOAgAAQBAJ\&oi=fnd\&pg=PP1\&dq=sti mulating $+\mathrm{a}+$ person $\% 27 \mathrm{~s}+$ sensory+to+increase+the+quantity+of + selling+their+products $\&$ ots $=6$ -G0Ljrra3\&sig=_sKhPVEGN-S6YEzfqApS-RG7fQQ\&redir_esc=y\#v=onepage\&q\&f=false

Shiraishi, T. (2004). The Rise of New Urban Middle Classes in Southeast Asia: What is its national and regional significance? Discussion Papers. https://ideas.repec.org/p/eti/dpaper/04011.html

Singh, S. (2020). Impact of Neuromarketing Applications on Consumers. Journal of Business and Management, 26(2), 33-52. https://doi.org/10.6347/JBM.202009_26(2).0002

Suyadi, Nuryana, Z., \& Fauzi, N. A. F. (2021). Membangun Bisnis Ekonomi Islam Perspektif Neuromarketing Di Masa Pandemic Covid-19. Islamic Economics, Finance, and Banking Review, l(2). https://doi.org/10.1016/J.IJDRR.2020.101848

Thaler, R. H. (2000). From Homo Economicus to Homo Sapiens. Journal of Economic Perspectives, 14(1), 133-141. https://doi.org/10.1257/JEP.14.1.133

The evolving Indonesian consumer November 2013 Rohit Razdan Mohit Das Ajay Sohoni. (n.d.).

Ulman, Y. I., Cakar, T., \& Yildiz, G. (2014). Ethical Issues in Neuromarketing: "I Consume, Therefore I am!" Science and Engineering Ethics 2014 21:5, 21(5), 1271-1284. https://doi.org/10.1007/S11948-014-9581-5

Vecchiato, G., Astolfi, L., De, F., Fallani, V., Toppi, J., Aloise, F., Bez, F., Wei, D., Kong, W., Dai, J., Cincotti, F., Mattia, D., \& Babiloni, F. (2011). On the Use of EEG or MEG Brain Imaging Tools in Neuromarketing Research. Computational Intelligence and Neuroscience, 2011, 12. https://doi.org/10.1155/2011/643489

Voorveld, H. A. M., Fakkert, M. S., \& van Reijmersdal, E. A. (2017). Materialistic girls watching a materialistic world: Fashion TV series and women's copy-cat intentions. Communications, 42(2), 239-251. https://doi.org/10.1515/COMMUN-20170018/MACHINEREADABLECITATION/RIS

Why Google has $200 \mathrm{~m}$ reasons to put engineers over designers | Google | The Guardian. (n.d.). Retrieved December 2, 2021, from https://www.theguardian.com/technology/2014/feb/05/whygoogle-engineers-designers

Wijaya, Y. (2007). Teologi Ekonomi Kontekstual Sebagai Respon Terhadap Konsumerisme. Jurnal Orientasi Baru, 16(2), 105-113.

Wilson, R. M., Gaines, J., \& Hill, R. P. (2008). Neuromarketing and Consumer Free Will. Journal of Consumer Affairs, 42(3), 389-410. https://doi.org/10.1111/J.1745-6606.2008.00114.X 